\title{
W obliczu rzeczy ostatecznych. Nowotestamentowa parabola o pannach mądrych i pannach głupich (Mt 25, 1-13) jako motyw w ikonografii średniowiecznej
}

Tekst zawartej w Ewangelii wg św. Mateusza przypowieści o pannach roztropnych i nierozsądnych mówi:

Wtedy [w dniu Sądu Bożego] z królestwem niebieskim będzie podobnie jak z dziesięcioma pannami, które wzięły lampy i wyszły naprzeciw pana młodego. Pięć z nich było głupich, a pięć mądrych. Głupie, wziąwszy lampy, nie zabrały z sobą oliwy. A mądre wzięły razem z lampami naczynia $\mathrm{z}$ oliwą. Kiedy pan młody się spóźniał, ogarnęła je senność i wszystkie zasnęły. O północy rozległo się wołanie: - „Pan młody nadchodzi, wyjdźcie mu naprzeciw". Wtedy wszystkie panny zerwały się ze snu i przygotowały lampy. A głupie powiedziały do mądrych: - „Dajcie nam trochę waszej oliwy, bo nasze lampy gasną”. Lecz mądre odpowiedziały: - „O nie! Nie wystarczyłoby dla was i dla nas. Idźcie raczej do sprzedawców i kupcie sobie”. A kiedy tamte poszły kupować, nadszedł pan młody i te, które były gotowe, weszły razem z nim na wesele. I zamknięto drzwi. W końcu przychodzą i pozostałe panny i mówią: „Panie, panie, otwórz nam!” - On zaś odpowiedział: „Zaprawdę powiadam wam: Nie znam was. Czuwajcie więc, bo nie znacie dnia ani godziny" (Mt 25, 1-13)1.

Apologeci i Ojcowie Kościoła zinterpretowali parabolę o pannach mądrych i głupich zmierzających na uroczystości weselne w kontekście eschatologicznym, postrzegając ją jako zapowiedź Paruzji i Sądu Ostatecznego, na co niewątpliwy wpływ miała również kolejność wydarzeń opisanych w 25. rozdziale Ewangelii wg św. Mateusza, który wpierw umieścił przypowieść

Cyt. za: Pismo Święte. Stary i Nowy Testament, red. ks. M. Peter, ks. M. Wolniewicz, Poznań 2010, s. 1431. 
o pannach (wersety 1-13), następnie o talentach (wersety 14-30), by na końcu zawrzeć opis Sądu Ostatecznego (wersety 31-46) ${ }^{2}$. Wspomniana w paraboli uczta weselna symbolizowała państwo Boże, a podążający na nią pan młody, oblubieniec, odnosił się do postaci Chrystusa, który jako Sędzia powróci na świat w Dniu Pańskim, wskrzesi umarłych niczym pan młody budzący swe śpiące oblubienice oraz podzieli ludzkość na zbawionych (identyfikowanych z pannami roztropnymi) i potępionych (kojarzonych z pannami nierozsądnymi) ${ }^{3}$. Nie bez znaczenia pozostawała symbolika niesionych przez panny lamp, wypełnionych oliwą lub pustych oraz liczba panien. W Biblii lampa oliwna (hebr. nir, gr. lychnos, lampas) pojawia się w różnych kontekstach jako łatwo zrozumiały, dobitny symbol znaczenia światła - w Starym Testamencie będącego przejawem mocy, obecności Boga (1 Sm 3, 3; 2 Sm 22, 29; Hi 29,3 ) i Jego przykazań (Ps 119, 105) ${ }^{4}$. W nowotestamentowej przypowieści zapalone lampy panien mądrych stają się metaforą ich odpowiedzialności, a przede wszystkim stanu gotowości na nadejście Oblubieńca - Chrystusa w dniu Sądu Bożego. Oliwa podsycająca płomień kaganków panien roztropnych to symbol dobrych uczynków zbliżających człowieka do zbawienia i życia wiecznego ${ }^{5}$, natomiast przygasające lampy panien głupich odnoszą się do dóbr i uciech doczesności, przypominają o odrzuceniu przez człowieka wartości duchowych, podkreślają utratę witalności u tych, którzy dopuszczają się zła, i tym samym pogrążają się w ciemności skłaniającej ich ku śmierci i zapomnieniu przez Boga (por. Hi 18, 5-21) ${ }^{6}$. Patres Ecclesiae (m.in. Orygenes, Metody z Olimpu, Hieronim, Grzegorz Wielki, Beda Czcigodny) związali liczbę panien z symboliką pięciu zmysłów ludzkich ${ }^{7}$, które z jednej strony mogą służyć kontemplacji utożsamianej z pannami roztropnymi,

2 Z. Kliś, Paruzja. Przedstawienie Sądu Ostatecznego w sztuce średniowiecznej Europy Środkowej, Kraków 1999, s. 184-185.

3 W Starym Testamencie wielokrotnie mianem oblubieńca/męża określa się postać Boga Ojca, którego oblubienicą/żoną jest naród Izraela (cf. np. Iz 54, 4-5 i 62, 5; Jr 2, 2; Oz 1, 1-3, 5); R. T. France, The Gospel According to Matthew: An Introduction and Commentary, Leicester 1985, s. 350.

4 Encyklopedia biblijna, red. P. J. Achtemeier, tłum. G. Berny, M. Bogusławska i in., Warszawa 1999, s. 663; L. Ryken, J. C. Wilhoit, T. Longman III, Słownik symboliki biblijnej. Obrazy, symbole, motywy, metafory, figury stylistyczne i gatunki literackie w Piśmie Świętym, przeł. Z. Kościuk, Warszawa 2003, s. 419.

5 A. Jankowski, K. Romaniuk, L. Stachowiak, Komentarz praktyczny do Nowego Testamentu, cz. 1, Poznań-Warszawa 1975, s. 130.

6 L. Ryken, J. C. Wilhoit, T. Longman III, Słownik symboliki..., s. 420.

7 Vide Z. Kliś, Paruzja..., s. 181-183. 
z drugiej - potrafią być źródłem rozkoszy kojarzonej z osobami panien nierozsądnych. Arnobiusz nadał trzem pannom mądrym nazwy trzech cnót kardynalnych: jedną określił jako czystość, a jedną jako miłosierdzie/ jałmużnę. Cezary z Arles identyfikował panny z cnotami i występkami, zaś Hraban Maur przekazywał, iż panny roztropne są dziewicami na ciele i w duchu, podczas gdy panny nierozsądne zachowały fizyczne dziewictwo, lecz nie umieją czynić dobra. Honoriusz z Autun również łączył liczbę panien z symboliką pięciu zmysłów, ale także Trójcy Świętej, radości i miłości, ponadto cnotami Boskimi oraz „castitas corporis et animae" ${ }^{\text {. Pomijając }}$ rozważania wspomnianych myślicieli chrześcijańskich, należy powiedzieć, że w czasach starożytnych piątkę postrzegano jako cyfrę związaną z symboliką miłosną, istotną w kontekście obrzędów weselnych, o których wszak mowa w przypowieści spisanej przez Mateusza. Pitagorejczycy dopatrywali się w piątce spotkania męskiej trójki z żeńską dwójką i małżeńskiego zespolenia, zresztą w antycznej Grecji przyjęło się określać piątkę mianem gamos, czyli dosłownie „zaślubin”. W Babilonii piątka stała się cyfrą przynależną bogini miłości Isztar, zaś na planie pięcioboku rozplanowana została świątynia Wenus w Baalbek. Platon wspominał w Timajosie, że w uroczystościach weselnych powinno uczestniczyć dokładnie pięciu gości. Grecy obrali na weselne symbole jabłko, pigwę i winorośl ze względu na kształt ich kwiatów składających się z pięciu płatków, natomiast Rzymianie podczas ceremonii zaślubin używali pięciu pochodni9.

W malarstwie motyw panien mądrych i głupich pojawił się stosunkowo wcześnie, bo już w I połowie III w. po Chrystusie przedstawiono je na fresku w domu modlitw w Dura Europos (obecnie w Yale University Art Gallery) ${ }^{10}$. Na malowidle ukazanych zostało kilka kobiet zmierzających w stronę konstrukcji zwieńczonej dwuspadowo (być może namiotu), na tle którego widać dwie gwiazdy/komety. Współcześnie jedynie dwie sylwetki są całkowicie widoczne, ponadto zachowały się fragmenty (lewa ręka oraz część torsu) trzeciej postaci. Panny ubrane są w białe stroje, ich głowy przykrywają welony, $\mathrm{w}$ prawych dłoniach niosą pochodnie, w lewych dzierżą bliżej nieokreślone naczynia. Zachowane szczątkowo ślady w pozostałych partiach malatury

Ibidem, s. 183.

9 O starożytnej symbolice piątki jako cyfry o znaczeniu miłosnym vide M. Lurker, Przesłanie symboli $w$ mitach, kulturach i religiach, tłum. R. Wojnakowski, Kraków 1994, s. 178.

10 Vide J. Pijoan, The Parable of the Virgins from Dura-Europos, "The Art Bulletin" 1937, No. 4, s. 592-595. 
pozwalają sądzić, że wspomnianym trzem postaciom towarzyszyły jeszcze dwie, a być może w Dura Europos przedstawiono wszystkie dziesięć panien. Niekiedy scenę odczytuje się jako wizualizację Marii Magdaleny, Marii, matki Jakuba, i Salome podążających wielkanocnym rankiem do grobu Jezusa celem namaszczenia jego ciała (Mk 16, 1-2). W myśl takiej interpretacji, trzymane przez kobiety naczynia miałyby być miskami z balsamem, pochodnie miałyby rozświetlać im drogę w ciemnościach nocy, gwiazdy/ komety symbolizowałyby wtedy zmartwychwstanie Chrystusa. Jednakowoż odnalezione na malunku pozostałości dwóch par stóp świadczą o tym, że łącznie przedstawiono pięć postaci - pięć panien mądrych, zmierzających $\mathrm{w}$ stronę lokum pana młodego $\mathrm{z}$ zapalonymi lampami oraz naczyniami wypełnionymi oliwą ${ }^{11}$.

Opisana przez Mateusza przypowieść funkcjonowała jako temat również w malarstwie katakumbowym, niejednokrotnie prezentującym biblijne historie traktujące o zmartwychwstaniu i życiu pośmiertnym. Wyobrażenia paraboli spotykane na ścianach wczesnochrześcijańskich nekropolii miały potwierdzać, „że zmarły uważnie oczekiwał powrotu Chrystusa i chociaż zapadł w sen, jest stale gotów go powitać" ${ }^{\prime 2}$. Wykonany na początku IV stulecia fresk w Coemetrium Ostrianum przy Via Nomentana przedstawia oblubieńca jako Chrystusa świętującego $\mathrm{z}$ wybranymi przy stole weselnym, również z pannami roztropnymi, przy czym zobrazowano tylko cztery z nich, bowiem miejsce piątej z dziewic zarezerwowano dla zmarłego właściciela grobu, gdzie zobrazowana została przypowieść. Ponadto przed drzwiami stoi pięć panien nierozsądnych, bezskutecznie próbujących dostać się na ucztę. Malowidło na lunecie arcosolium w katakumbach Cyriaka przy Via Tiburtina (według inskrypcji datowane na 370 r.) pokazuje Chrystusa błogosławiącego prawą ręką, wokół którego zebrało się dziesięć panien - stojących po Jego prawicy, stronie zbawionych, pięć mądrych z zapalonymi pochodniami oraz zgromadzonych po Jego lewicy, stronie potępionych, pięć głupich trzymających pochodnie zgaszone, powywracane spodem do góry ${ }^{13}$.

11 R. M. Jensen, Baptismal Imagery in Early Christianity: Ritual, Visual and Theological Dimensions, Grand Rapids 2012, s. 201.

12 M. Zlatohlávek, C. Rätsch, C. Müller-Ebelling, Sąd Ostateczny. Freski, miniatury, obrazy, tłum. A. Kleszcz, Kraków 2002, s. 55.

13 Symbolika stron, stosowana we wczesnochrześcijańskiej ikonografii panien, odegrała istotną rolę zwłaszcza w rzeźbiarskich ujęciach motywu, licznie reprezentowanych w portalach kościołów romańskich i gotyckich. Objaśnienie istoty owej symboliki znajduje się w paraboli o owcach i kozłach, także wspomnianej w 25. rozdziale Ewangelii wg św. Mateusza, vide Mt 25, 31-46. 
Na iluminacji w Ewangeliarzu z Rossano (VI w.) panny roztropne właśnie przekroczyły bramę królestwa niebieskiego, stoją na tle rajskiego ogrodu, przez który przepływają cztery rzeki ${ }^{14}$, tymczasem panny nierozsądne dobijają się do niebiańskich wrót zatrzaśniętych przez Chrystusa. Wszystkie dziesięć panien niesie w prawych dłoniach pochodnie - u panien mądrych gorejące mocnym płomieniem, u głupich już dogasające, w lewych rękach dzierżą naczynia na oliwę - puste u nierozsądnych i wypełnione płynem u roztropnych. Opozycję między postaciami widać również w kolorystyce ich strojów. Panny głupie ubrane są $\mathrm{w}$ kolorowe suknie, kiedy sylwety panien mądrych okrywają białe szaty, w jakie podług tekstu Apokalipsy przyodziani będą wszyscy ci, którzy staną przed obliczem Baranka, aby go wielbić15.

Wizualizacje paraboli często pojawiały się w malarstwie freskowym XII i XIII w. Z XII stulecia pochodzą wyobrażenia przypowieści m.in. w katedrze w Anagni, kościele San Quirce w Pedret (Katalonia), kościele w Idensen (ok. 1120-1130), kaplicy zamku Hocheppan w południowym Tyrolu (ok. 1200). $\mathrm{Na}$ XIII w. datuje się wizerunki panien mądrych i głupich w kościołach w Nideggen oraz św. Małgorzaty w tyrolskiej miejscowości Lana (ok. 1215) ${ }^{16}$.

Przypowieść dwukrotnie zobrazowano w jedynej zachowanej współcześnie kopii Credo Jeana de Joinville, powstałej ok. 1287 r. (obecnie w zbiorach Biblioteki Narodowej w Paryżu $)^{17}$. Przedstawienia paraboli jako tematu związanego z Paruzją i Sądem Ostatecznym występują w manuskrypcie pośród wielu scen chrystologicznych, m.in.: zstąpienia Jezusa do piekieł, Zmartwychwstania, Zesłania Ducha Świętego, Wniebowstąpienia czy wyobrażenia Chrystusa zasiadającego po prawicy Boga Ojca. Na pierwszej z miniatur panny roztropne przekraczają bramę królestwa niebieskiego, ponad którą ukazany został Chrystus zwracający się do panien głupich słowami: „Nescio vos”. Druga iluminacja przedstawia panny nierozsądne („Quinque virgines fatue") niosące odwrócone lampy i błagające panny mądre o odrobinę oliwy: „Date nobis de oleo vestro”. Ponad wrotami raju, przed którymi stoją panny głupie - podobnie jak na pierwszej iluminacji - objawia się postać Mesjasza,

14 Cztery rzeki wypływające z Edenu: Piszon, Gichon, Chiddekel i Perat (Rdz 2, 10-14).

15 Vide Ap 7, 9-10.

16 O malarskich reprezentacjach paraboli w XII-XIII w. vide np. L. Réau, Iconographie de l'art chrétien. Iconographie de la Bible. Nouveau Testament, t. 2, Paris 1957, s. 358; H. Sachs, Jungfrauen, Kluge und Törichte, [w:] Lexikon der christlichen Ikonographie, t. 2, red. E. Kirschbaum, Rom-Freiburg-Basel 1970, szp. 461.

17 Na temat Credo Jeana de Joinville pisał L. J. Friedman, On the Structure of Joinville's Credo, "Modern Philology" 1953, Vol. 51, No. 1, s. 1-8; idem, Text and Iconography for Joinville’ s Credo, Cambridge 1958. 
wypowiadającego słowa: „Amen dico vobis; nescio vos”. W tym samym czasie pięć panien roztropnych („Quinque virgines prudentes”) przechadza się po niebiańskim ogrodzie, odpowiadając pannom nierozsądnym na ich błagania o użyczenie oliwy: „Ite et emite vobis”.

W XII i XIII w. biblijna przypowieść stała się motywem powszechnie reprezentowanym w dekoracjach rzeźbiarskich kościołów francuskich. Już ok. 1120 r. wizerunki panien umieszczono na dwóch kapitelach krużganku katedry Saint-Étienne w Tuluzie, natomiast po raz pierwszy wizualizację paraboli związano bezpośrednio z wyobrażeniem Sądu Ostatecznego w centralnym portalu zachodniej fasady bazyliki Saint-Denis w Paryżu (ok. 1140) ${ }^{19}$. Jak zauważył Otto von Simson, w paryskim kościele - zgodnie z koncepcją opata Sugera - nowotestamentowa przypowieść związana została z symboliką Bramy Niebios, stając się fragmentem porta coeli - fasady pojmowanej jako próg, którego przekroczenie miało być jednoznaczne z opuszczeniem sfery życia doczesnego i wstąpieniem do świata wieczności ${ }^{20}$. Umiejscowione naprzeciwlegle w ościeżach portalu cztery pary panien mądrych i głupich są prowadzone ku centralnej postaci Chrystusa przez dwie panny przewodniczki, ukazane w narożach tympanonu z Sądem Ostatecznym, zobrazowanym raczej według tekstu Ewangelii wg św. Mateusza (podobnie jak w Autun, Conques i Beaulieu), aniżeli Apokalipsy św. Jana ${ }^{21}$. Przewodniczka panien nierozsądnych, dotarłszy ze swą zgaszoną lampą do rajskich wrót, chwyta rozpaczliwie ich kołatkę, bezskutecznie próbując je przebyć. Równocześnie przewodniczka panien roztropnych wkracza dumnie w progi budowli zwieńczonej blankami, stanowiącej wyobrażenie niebiańskiego miasta. W sztuce francuskiej reprezentacje ewangelicznej paraboli stały się tematem pobocznym, uzupełniającym dla przedstawień "Jugement dernier”, spychanym w formie reliefu na portalowe odrzwia, nadproża lub archiwolty ${ }^{22}$. W XII w., wzorem Saint-Denis, płaskorzeźbione figury panien mądrych i głupich zaczęły okalać portale Sądu Ostatecznego romańskich kościołów w prowincjach Poitou (Saint-Hilaire de Melle i Saint-Nicolas de Civray w Charroux) oraz Saintonge (w Chadenac, Aulnay, Corme-Royal), ponadto w akwitańskiej miejscowości Mimizan. W XIII stuleciu wizerunki panien pojawiły się w portalach katedr w Sens (ok. 1200), Laon, Paryżu (Notre-Dame, ok. 1220-1230), Amiens (1220-1235),

\footnotetext{
18 Ibidem, s. 81.

19 L. Réau, Iconographie..., s. 357.

20 O. von Simson, Katedra gotycka. Jej narodziny i znaczenie, tłum. A. Palińska, Warszawa 1989, s. 156.

21 Z. Kliś, Paruzja..., s. 178.

22 L. Réau, Iconographie..., s. 354.
} 
Poitiers (portal św. Tomasza), Bazas, Auxerre (1260-1270). W ostatniej ćwierci XII w. tradycja przedstawiania panien na reliefach pokrywających kościelne portale przeniknęła na obszary niemieckojęzyczne, a jej pierwszą materializacją stał się ukończony około 1180 r. portal św. Galla (Galluspforte) w katedrze w Bazylei ${ }^{23}$. Wizualizację przypowieści osadzono w nadprożu usytuowanym poniżej tympanonu z Sądem Ostatecznym, zobrazowanym jako scena Traditio Legis, w której uczestniczą zasiadający na tronie Chrystus wraz ze świętymi Piotrem i Pawłem. Panny mądre wita we wrotach do krainy niebieskiej sam Zbawiciel, obojętny wobec panien głupich, bezcelowo dobijających się do zamkniętych bram raju. Eschatologiczną wymowę bazylejskiego portalu dodatkowo podkreśla m.in. sześć zlokalizowanych w ościeżach płaskorzeźbionych personifikacji czynów miłosierdzia, wspomnianych w opisie Sądu Bożego w Ewangelii wg św. Mateusza ${ }^{24}$. Podobnie jak w Bazylei, reprezentację nowotestamentowej paraboli umieszczono w nadprożu portalu kościoła parafialnego w Egisheim (ok. 1230), natomiast w XIV w. przypowieść ukazano w portalach kolegiaty w Wetzlar oraz katedry w Ulm (ok. 1390).

Pomiędzy XIII a XV stuleciem w portalach kościołów na obszarze Rzeszy postaci panien zaczęly przybierać formę nadnaturalnych rozmiarów, potężnych statui uzupełniających monumentalne kompozycje Sądu Ostatecznego. W latach ok. 1240-1250 wykonano posągi panien w katedrze w Magdeburgu (Paradiesvorhalle), następnie podobne rzeźby pojawiły się w katedrach w Strasbourgu (ok. 1280), Fryburgu Bryzgowijskim (1280-1285), Bazylei (1290-1300), Hamburgu (ok. 1300), Erfurcie (Triangelportal; ok. 1350), Schwäbisch-Gmünd (ok. 1360), Landschut (ok. 1465) oraz Bernie (dzieło pochodzącego z Westfalii rzeźbiarza Erharta Künga; ok. 1475), ponadto z lat 1320-1330 pochodzą figury panien w kościele św. Marcina w Brunszwiku, również po 1320 r. posadowiono statuy w tzw. Portalu Panieńskim (Brautportal) kościoła św. Sebalda w Norymberdze ${ }^{25}$. W przypadku monumentalnych ujęć rzeźbiarskich tematu szczególną rolę odgrywała fizjonomia panien, pozbawiona cech idealizacji. Panny głupie wyobrażano w gestach rozpaczy, melancholii, ich twarze wykrzywiały się w grymasie niepokoju, gniewu, szaleństwa, podczas gdy mądre jawiły się w powściągliwych pozach, jako istoty spokojne, opanowane, o pogodnych obliczach wyrażających ich

23 J. A. Holladay, Wise and Foolish Virgins, [w:] Medieval Germany: An Encyclopedia, ed. J. M. Jeep, New York 2001, s. 395.

24 Vide Mt 25, 35-36.

25 Vide L. Réau, Iconographie..., s. 354-355, 357-358; H. Sachs, Jungfrauen..., szp. 462; J. A. Holladay, Wise and Foolish..., s. 395-396; Z. Kliś, Paruzja..., s. 179, przyp. 71. 
wewnętrzną harmonię. Panny roztropne przeważnie odziane były w skromne, luźne suknie, kiedy ciała nierozsądnych okrywały niedbale ułożone, mocno opinające ich talię szaty. Panny mogły posiadać przewodników. Roztropne najczęściej wiodła do bram królestwa niebieskiego Eklezja, czyli Kościół przedstawiany w rzeźbie gotyckiej pod postacią dumnie kroczącej przed siebie młodej, pięknej kobiety, dostojnie ubranej, przeważnie w koronie, niosącej w dłoniach krzyż, narzędzie Męki Pańskiej, oraz kielich wypełniony odkupieńczą krwią Chrystusa - symbol Nowego Przymierza (zob. Łk 22, 20). Panny nierozsądne podążały za Synagogą - żeńską personifikacją wiary judaistycznej, która nie uznała Jezusa za Mesjasza, w sztuce gotyku często ukazywaną - niczym Eklezja - jako młoda, urodziwa niewiasta, jednak pochylająca głowę w dół lub ślepa, z oczami zawiązanymi opaską ${ }^{26}$, niosąca złamaną włócznię (nawiązującą do tej, którą Longin przebił bok Chrystusa), niekiedy wypuszczająca z rąk tablice Dekalogu bądź zwoje Tory, czasami trzymająca w dłoni koźli lub barani łeb - znak starotestamentowej ofiary (Kpł 1, 1-7, 38). Eklezję i Synagogę uczyniono przewodniczkami panien choćby w katedrach w Magdeburgu, Fryburgu Bryzgowijskim i Erfurcie ${ }^{27}$. Niekiedy panny głupie uwodził diabeł przedstawiony jako Książę/ Pan Świata, czyli Mundus (łac. Princeps Mundi) ${ }^{28}$ - zachowujący się zalotnie

26 Akcentowanie ślepoty Synagogi w ikonografii średniowiecznej miało swoją genezę przede wszystkim we fragmencie 2. Listu św. Pawła do Koryntian, traktującym o zaślepieniu Mojżesza i wyznawców judaizmu (2 Kor 3, 12-18); S. Lewis, Tractatus adversus Judaeos in the Gulbenkian Apocalypse, "The Art Bulletin” 1986, No. 4, s. 548 , przyp. 24.

27 Ponadto alegorie Eklezji i Synagogi - niekoniecznie w związku z parabolą o pannach - pojawiły się w programach rzeźbiarskich elewacji katedr gotyckich w Strasbourgu, Bambergu, Minden, Wormacji, Reims, Paryżu, w kościele Saint-Seurin w Bordeaux, również w katedrach angielskich - w Rochester, Lincoln, Salisbury, Winchester. Szerzej o symbolice oraz ikonografii Eklezji i Synagogi m.in. w publikacjach: M. Schlauch, The Allegory of Church and Synagogue, "Speculum" 1939, Vol. 14, No. 4, s. 448-464; L. Réau, Iconographie..., s. 744-747; W. S. Seiferth, Synagoge und Kirche im Mittelalter, München 1964; W. Greisenegger, Ecclesia und Synagoge, [w:] Lexikon..., t. 1, red. E. Kirschbaum, Rom-Freiburg-Basel 1968, szp. 569-578; H. Rosenau, Ecclesia et Synagoga, [w:] Encyclopaedia Judaica, t. 6, eds. F. Skolnik, M. Berenbaum, Detroit-New York-San Francisco 2007, s. 88; R. Michael, A History of Catholic Antisemitism: The Dark Side of the Church, New York 2008; N. Rowe, The Jew, the Cathedral, and the Medieval City: Synagoga and Ecclesia in the Thirteenth Century, Cambridge 2011.

28 Szatan zostaje określony mianem „władcy świata” we fragmentach Ewangelii wg św. Jana, vide J 12, 31; 14, 30. 
przystojny mężczyzna, odziany w bogate szaty, niosący w rękach kwiaty lub owoce, jednak odrażający z tyłu, którego otwarte plecy - naznaczone ranami i bliznami, obrosłe we wrzody - zapełniały ropuchy, węże i robaki, stworzenia chtoniczne, diabelskie, zasiedlające czeluści podziemia, według trzynastowiecznych interpretacji Bertholda $z$ Regensburga oraz św. Mechtyldy z Magdeburga symbolizujące grzeszników ${ }^{29}$. Mundus - porażające swym fizycznym dualizmem wcielenie dwulicowości świata - objął funkcję kusiciela panien nierozsądnych w portalu katedry w Strasbourgu, gdzie ubrany $\mathrm{w}$ dworski strój, z różaną koroną na głowie, zwodzi jedną z dziewic, wyciągając chytrze dłoń, w której trzyma jabłko - znak ponętności grzechów. Dla opozycji ukazanym naprzeciwko pannom roztropnym przewodzi Chrystus. W portalu katedry w Bazylei Princeps Mundi dzierży w ręce kwiat będący symbolem zwodniczych radości świata. Ponadto figura Mundusa jako uwodziciela panien głupich pojawia się w katedrze we Fryburgu Bryzgowijskim. Jedną z najwcześniejszych reprezentacji tematu nowotestamentowej paraboli na obszarze polskim stały się rzeźbione postaci panien ustawione na kapitelach ościeży Złotej Bramy na Zamku Wysokim w Malborku, datowanej na ostatnią ćwierć XIII w. Przedstawione po lewej stronie portalu panny roztropne i usytuowane na prawo dziewice nierozsądne odziane są $\mathrm{w}$ długie, różnobarwne suknie z wąskimi rękawami. Ramiona panien oblekają podtrzymywane przez nie płaszcze - mocno pofałdowane u dołu, układające się w diagonalno-wertykalne pasma draperii. Panny mądre, których głowy zdobią kwietne wianki dzierżą w prawej dłoni lampy oliwne $\mathrm{w}$ formie kielicha, natomiast bardziej ekspresyjne w wyrazie panny głupie - o utrapionych spojrzeniach, ukazane bez wianków na głowach, pogrążone w gestach zakłopotania, smutku, rezygnacji - niosą puste lampy odwrócone dnem do góry ${ }^{30}$. Panny prowadzą Eklezja i Synagoga, wyobrażone pośrodku wewnętrznego wałka archiwolty. Głowę Eklezji, przewodniczki niewiast roztropnych, wieńczy korona, po jej włosach spływa na ramiona welon. Alegoryczna postać ubrana jest w długą suknię, którą przykrywa wierzchni kaftan z trójkątnym

29 Na temat postaci Mundusa vide J. Jagla, Wieczna prośba i dziękczynienie. O symbolicznych relacjach między sacrum i profanum w przedstawieniach wotywnych $z$ obszaru Polski Centralnej, Warszawa 2009, s. 197-199.

30 Obecny w średniowiecznej ikonografii panien głupich motyw odwróconych lamp miał zostać bezpośrednio zainspirowany tekstem dramatu Sponsus: Nos Virgines, que ad vos venimus Negligenter oleum fundimus (ok. 1130), bowiem nie wspomina o nim Ewangelia wg św. Łukasza, zaś w sztuce bizantyńskiej panny były wyobrażane z pochodniami; vide B. Jakubowska, Złota Brama w Malborku. Apokaliptyczne bestiarium w rzeźbie średniowiecznej, Malbork 1989, s. 43. 
dekoltem, identyczny, jak ten okrywający księżną Gertrudę na nagrobku w Kwedlinburgu oraz oblekający korpus Małgorzaty Duńskiej na płycie sarkofagu w kościele pocysterskim w Bad Doberan ${ }^{31}$. W lewej ręce Eklezja trzyma kielich - wspominany już symbol Nowego Przymierza, zaopatrzony w pokaźną czarę złączoną wklęskiem z nodusem zdobionym perłami, w prawej dłoni alegoria dzierży krzyż obwiązany chorągwią. Prowadząca panny nierozsądne Synagoga, z głową pochyloną w dół na znak swej porażki z Eklezją, niesie w prawej ręce łeb kozła oraz złamane w trzech miejscach drzewce sztandaru rzuconego u jej stóp, w lewej dłoni, wzniesionej nad koźlą czaszką, trzyma nóż - narzędzie obrzezania ${ }^{32}$. Z głowy Synagogi zsuwa się niedbale wdziana korona. Zasłonięte opaską oczy uwydatniają jej duchowe zaślepienie. Ukazane w Złotej Bramie figury panien oraz ich przewodniczek otoczone są przez wyobrażenia różnych zwierząt oraz istot hybrydalnych (m.in. syreny, centaura, smoka, dzika, kozła), obdarzonych w kulturze chrześcijańskiej średniowiecza negatywną symboliką i uznawanych za wcielenia zła, diabła, herezji, nieczystości, gniewu, według Bogny Jakubowskiej - kreujących w malborskim portalu wizję bestiarium szatana ${ }^{33}$. Zdaniem badaczki:

W rzeźbiarskim programie Złotej Bramy idea Sądu Ostatecznego została zaznaczona wyraźnie. Jednak dla materialnej postaci tej idei nie wybrano powszechnie niemal obowiązującego wzorca ikonograficznego w postaci majestatycznej kompozycji Sądu, której istotą jest teofania. Wyizolowanie z centrum kompozycji motywu Chrystusa - Sędziego, osadzonego w pewnym od niej oddaleniu, na zworniku sklepienia kruchty i zrezygnowanie z reprezentacyjnej formuły Maiestas Domini wpłynęło zasadniczo na dowartościowanie figur Panien i obu ich przewodniczek. [...] Dla wyrażenia idei Sądu Ostatecznego przyjęto zatem tutaj formę mniej typową, utajoną właśnie w orszaku Panien Mądrych i Głupich z figurami Eklezji i Synagogi oraz $\mathrm{w}$ apokaliptycznym bestiarium ${ }^{34}$.

Niemniej zgoła odmiennie symbolikę Złotej Bramy odczytywał Szczęsny Skibiński, według którego portal, pozbawiony przedstawienia Sądu

$31 \quad$ Ibidem, s. 22.

32 Nóż jako atrybut Synagogi występował stosunkowo rzadko. Pojawia się m.in. na ilustracji w Hortus Deliciarum Herrady z Landsbergu (ok. 1180); L. Réau, Iconographie..., s. 746.

33 O ikonografii i symbolice fauny zobrazowanej w malborskim portalu vide B. Jakubowska, Złota Brama..., passim.

34 Ibidem, s. 135. 
Ostatecznego, bardziej niż eschatologicznemu został podporządkowany wątkowi eklezjologicznemu. Historyk sztuki eksponuje kilka elementów. Pierwszym jest wyobrażenie panien roztropnych i nierozsądnych, w którym niekoniecznie należy dopatrywać się podziału na zbawionych i potępionych, ewidentne w reprezentacjach paraboli towarzyszących scenom Sądu Bożego. Kolejny to umieszczone powyżej wizerunki Eklezji i Synagogi, wedle alegorycznej interpretacji Pieśni nad Pieśniami utożsamianych z osobami mistycznej oblubienicy oraz Sulamitki - byłej oblubienicy, odtrąconej, zwyciężonej, przez co przepełnionej nienawiścią. Trzeci to ukazana w kluczu zewnętrznej archiwolty postać Salomona ${ }^{35}$, starotestamentowego władcy, oblubieńca, sędziego i budowniczego świątyni, będącego prefiguracją Chrystusa - budowniczego Kościoła. Połączenie ich wszystkich z przedstawieniem Maiestas Domini na zworniku przedsionka służyło powiązaniu ewangelicznej przypowieści z Pieśniq nad Pieśniami, co dokonało się już w XII w. w dramacie liturgicznym Sponsus. Jak pisze Skibiński - ze względu na swą popularność i wartości dydaktyczne utwór ten był zapewne odgrywany przed portalem kościoła. Wprowadzenie do programu ikonograficznego reprezentacji Maiestas Domini, typowego dla przedstawień Sądu Ostatecznego ujęcia Chrystusa - Króla i Sędziego, pozwala traktować Złotą Bramę jako porta coeli - furtę Niebieskiego Jeruzalem, przed którą nastąpi Boski osąd - prowadzącą do kościelnego wnętrza utożsamianego $\mathrm{z}$ rajem, siedzibą zbawionych ${ }^{36}$.

$\mathrm{Na}$ Zamku Wysokim w Malborku motyw panien powtórzony został jeszcze w dolnej partii środkowego tympanonu przedsionka północnego kaplicy św. Anny z lat trzydziestych XIV w. W polu głównym przedstawiono scenę koronacji Marii, siedzącej wspólnie z Chrystusem na obszernym tronie, wokół którego zebrały się zastępy aniołów muzykujących na różnych instrumentach. Jezus, w koronie na głowie, dzierżący w lewej ręce królewskie jabłko, zakłada prawą dłonią koronę na głowę swej Matki, zwracającej się ku Niemu w geście adoracji. Poniżej, w dwóch panelach, ukazane zostały orszaki panien - po lewej stronie korowód niewiast mądrych, wiedzionych przez anioła do bram niebios, po prawej - pochód dziewic głupich, wprowadzanych przez diabła do piekła wyobrażonego jako paszcza potwora Lewiatana. Wszystkie panny - podobnie jak te w Złotej Bramie - odziane są w udrapowane suknie z długimi, wąskimi rękawami oraz płaszcze. Roztropne niosą wysoko uniesione lampy $\mathrm{w}$ formie kielicha, u nierozsądnych

35 B. Jakubowska dopatrywała się w tym miejscu przedstawienia diabła, władcy piekiet, cf. ibidem, s. 136.

36 Cf. S. Skibiński, Kaplica na Zamku Wysokim w Malborku, Poznań 1982, s. 132-145. 
wywrócone dnami do góry. W nietypowy sposób potraktowany został inny atrybut panien, mianowicie zdobiące ich skronie korony - powszechnie reprezentowany w ikonografii średniowiecza symbol cnoty, wytrwałości, wiary, błogosławieństwa, także życia wiecznego ${ }^{37}$. W malborskim tympanonie korony panien głupich, identyczne jak u mądrych, nie są założone odwrotnie ani - jak zwykle miało to miejsce w scenach Sądu Bożego - nie spadają $\mathrm{z}$ ich głów na znak potępienia ${ }^{38}$. Skibiński słusznie zauważył, że:

Tematykę rzeźby portalu północnego określić można jako mariologiczną interpretację eklezjologicznego programu wcześniej powstałej dekoracji Złotej Bramy. Podobnie jak w portalu wiodącym do wnętrza głównej kaplicy, tak i tu źródłem przedstawień tympanonu środkowego są komentarze łączące Pieśń nad Pieśniami z parabolą ewangeliczną o Pannach Mądrych i Głupich ${ }^{39}$.

Maria, wyniesiona do najwyższej godności królowej nieba, staje się tu Oblubienicą Chrystusa, będąc identyfikowaną z Eklezją. Już teksty apokryficzne opisywały Matkę Boską jako „wniesioną do swego Oblubieńca i posadzoną na jego tronie" ${ }^{\prime 4}$. Następnie pisarze epoki karolińskiej, Paschazjusz Radbert i Piotr Diakon, analizowali Pieśń nad Pieśniami w kontekście symboliki Marii - Oblubienicy Chrystusa, wreszcie Bernard z Clairvaux uznał Maryję za Pannę Mądrą, zaopatrzoną w lampę wypełnioną oliwą ${ }^{41}$. Podejmowane

37 O symbolice korony vide E. Hall, H. Uhr, Aureola and Fructus: Distinctions of Beatitude in Scholastic Thought and the Meaning of Some Crowns in Early Flemish Painting, “The Art Bulletin” 1978, No. 2, s. 249-270.

38 Korona często występowała jako atrybut panien w średniowiecznych tekstach misteryjnych, np. w Ludus de decem Virginibus (przechowywanym w wersji z trzeciej ćwierci XIV w. w Stadtarchiv w Mühlhausen oraz w wersji z 1428 r. w Hessische Landesmuseum und Hochschulbibliothek w Darmstadt) korony spadają z głów panien głupich zniewolonych łańcuchami. W utworze Künzelsauer Fronleichnamsspiel z 1479 r. (obecnie w Stadtarchiv w Schwäbisch Hall) Chrystus wręcza korony przebywającym w Królestwie Niebieskim pannom mądrym. Podobna scena niebiańskiej koronacji panien roztropnych przez Mesjasza znalazła się w niderlandzkim misterium Spiel van de V vroede en van de V dwaece Maegden sprzed 1500 r.; vide Z. Kliś, Paruzja..., s. 183.

S. Skibiński, Kaplica..., s. 147.

40 U. Bzówka, Treści ikonograficzne portalu grobowej kaplicy św. Anny na Zamku Krzyżackim w Malborku, „Roczniki Humanistyczne” 1975, t. 23, z. 5, s. 38.

41 B. Jakubowska, Malborska Summa theologica, [w:] T. Guć-Jednaszewska, B. Jakubowska, Z. Kruszelnicki, Studia z historii sztuki Gdańska i Pomorza, WrocławWarszawa-Kraków 1992, s. 201-202. 
jeszcze w starożytności i później w średniowieczu interpretacje wskazujące na relację Sponsa-Sponsus, zachodzącą między Marią a Chrystusem, identyfikowanym z Oblubieńcem również w ówczesnych objaśnieniach eschatologicznej przypowieści, sprawiły, że w XII stuleciu wizerunki panien mądrych i głupich zaczęły towarzyszyć przedstawieniom gloryfikacji Matki Boskiej $^{42}$ - najbardziej umiłowanej spośród wszystkich panien wezwanych przez Chrystusa do ślubnej komnaty, uznawanej za najmądrzejszą z dziewic - „Virgo prudentissima, określanej jako Forma virtutis oraz Virgo virginum" ${ }^{43}$. Niemniej w rzeźbie średniowiecznej, poza tympanonem w kaplicy św. Anny, nowotestamentową parabolę związano ze sceną koronacji Marii zaledwie trzykrotnie - w trzynastowiecznych portalach kościołów w Longpont, Liebfrauenkirche w Wormacji oraz w Lwówku Śląskim ${ }^{44}$. Ikonografia malborskiego tympanonu ujawnia ideę intercessio, wstawiennictwa Matki Boskiej za grzeszną ludzkość u Chrystusa - Sędziego. Człowiek średniowiecza wyniósł orędownictwo za wiernymi do najważniejszej funkcji intronizowanej Marii - według Autperta, wypełniającej w ten sposób patrocinium względem ludzkości, tytułowanej przez Pawła Diakona audiatrix, określanej przez Milo z Saint Amand jako protectrix i auxilliatrix, zwanej tutrix przez Szkota Eriugena ${ }^{45}$. W przedstawieniu w kaplicy św. Anny protekcja Marii wynikająca z Jej chwały, bliskości z Chrystusem oraz zbawczej działalności na ziemi, kontynuowanej teraz w niebie - obejmuje panny głupie - grzeszne i zmierzające ku wiecznemu potępieniu, lecz nadal mogące liczyć na litość i wsparcie ze strony swej Opiekunki.

W tympanonie powstałego na początku XIV w., być może nigdy nie ukończonego portalu kościoła w Małujowicach ukazane zostały trzy sceny „radości Marii” - u góry Wniebowzięcie, poniżej Hołd Trzech Króli oraz Nawiedzenie, zaś w pierwszym łuku archiwolty okalającej tympanon pojawia się szereg prymitywnych figurek - prawdopodobnie wyobrażenie panien roztropnych i nierozsądnych ${ }^{46}$. W latach ok. 1350-1360 temat ewangelicznej przypowieści podjęto na malowidłach pokrywających prezbiterium

42 W XII w. w kościele Notre-Dame-de-la-Couldre w Parthenay panny ukazano obok sceny Zwiastowania, natomiast w świątyni w Civray obok sceny Wniebowzięcia;

L. Réau, Iconographie..., s. 354.

43 B. Jakubowska, Malborska Summa..., s. 201.

44 Ibidem, s. 202.

45 Ibidem, s. 200.

46 T. Chrzanowski, M. Kornecki, Sztuka Śląska Opolskiego. Od średniowiecza do końca wieku XIX, Kraków 1974, s. 70. 
kościoła parafialnego w Strzelcach koło Sobótki ${ }^{47}$. Ukazane na ścianie północnej: korowód panien mądrych i spętanych grubym sznurem głupich, powstanie martwych z grobów oraz Sąd Ostateczny, ujawniający typ ikonograficzny Chrystusa w mandorli, jak również przedstawione na ścianie wschodniej paszcza Lewiatana i zstąpienie Jezusa do piekieł utworzyły wespół cykl eschatologiczny. Nowotestamentową parabolę ilustrują także malowidła w kaplicy opactwa cysterskiego w Lądzie nad Wartą, wykonane w latach ok. 1360-1370 z fundacji starosty wielkopolskiego Wierzbięty z Paniewic oraz okolicznych rodów szlacheckich. W programie dekoracyjnym kaplicy, podporządkowanym całkowicie woli fundatora i mającym „charakter prywatnego manifestu wyrażonego metodą obrazową", uwzględniono wątek traktujący o rzeczach ostatecznych, wyrażony poprzez reprezentację przypowieści o pannach, scenę zmartwychwstania umarłych oraz wizerunki Chrystusa jako Sędziego i pod postacią Baranka Bożego ${ }^{48}$. Panny roztropne ukazano w górnej strefie ściany południowej, powyżej sceny fundacyjnej, w której udział biorą: stojący pośrodku św. Jakub Starszy w stroju pielgrzyma, klęczący $z$ lewej strony fundator $\mathrm{z}$ rodziną, ofiarowujący model kaplicy oraz klęczący z prawej strony cystersi ${ }^{49}$. Panny mądre - wyróżnione nimbami wokół głów, ukoronowane, odziane w długie suknie o zróżnicowanej kolorystyce, niosące zapalone kaganki - witane są w niebiańskim progu przez anioła i Chrystusa wskazującego na umieszczone obok banderole, bez wątpienia zapełnione niegdyś wersetami Ewangelii. Panny głupie przedstawiono na ścianie północnej, ponad sceną walki św. Jerzego ze smokiem oraz figurą św. Marcina z żebrakiem. Odziane w dwubarwne suknie lub zdobione paskami niczym kostiumy błaznów, ujęte w gestach rozpaczy i przerażenia, po kolei gubiące korony, niosące lampy wypadające im z rąk, są popędzane przez diabły ku gardzieli Lewiatana.

$\mathrm{Na}$ fresku z przełomu XIV i XV w. pokrywającym ścianę północną katedry w Kwidzynie każdej z panien roztropnych towarzyszy anioł, podczas

47 Vide A. Orosz, Gotycka polichromia w kościele w Strzelcach Świdnickich, „Kwartalnik Opolski” 1956, nr 1 (5), s. 172-190; A. Karłowska-Kamzowa, Malarstwo ślaskie 12501450, Wrocław-Warszawa-Kraków 1979, s. 17-20, 117; Malarstwo gotyckie w Polsce. Katalog zabytków, red. A. S. Labuda, K. Secomska, Warszawa 2004, s. 92-93.

J. Domasłowski i in., Gotyckie malarstwo ścienne w Polsce, Poznań 1984, s. 113.

49 Na temat ikonografii malowideł w Lądzie vide ibidem, s. 113-115; Malarstwo gotyckie..., s. 63-65; Z. Białłowicz-Krygierowa, Malowidła ścienne zXIV wieku w dawnym opactwie cysterskim w Lądzie nad Wartą, Poznań 1957, s. 22-39; eadem, Malowidła ścienne..., rec. A. Karłowska, „Studia i Materiały do Dziejów Wielkopolski i Pomorza" 1962, t. 7, z. 1, s. 377-379. 
gdy panny nierozsądne, przedstawione poniżej z odwróconymi lampami i koronami spadającymi im z głów, podążają w orszaku z diabelskimi maszkarami ${ }^{50}$. Interesującym przykładem ikonografii nowotestamentowej przypowieści jest malowidło z początków XV stulecia w kościele filialnym w Hajdukach Nyskich ${ }^{51}$, zaskakujące brzydotą fizjonomii panien, zarówno głupich, jak i - co najbardziej dziwi - mądrych, oszpeconych przez zdeformowane rysy twarzy, wynikające czy to z nieudolności artysty czy chęci przełamania idealizowanej konwencji stylu pięknego ${ }^{52}$. W kolegiacie sandomierskiej pw. NMP parabolę ukazano na jednym $\mathrm{z}$ fresków wykonanych $\mathrm{w}$ prezbiterium między końcem XIV w. a 1434 r. z fundacji Władysława Jagiełły. Scena z pannami stanowi fragment wątku chrystologicznego, złożonego $\mathrm{z}$ tradycyjnego cyklu głównych wydarzeń ewangelicznych (tzw. dwunastu głównych świąt roku), poszerzonego o cykl działalności publicznej Chrystusa (cudów i przypowieści), a także cykle: pasyjny oraz Zmartwychwstania ${ }^{53}$. Ponadto z I poł. $\mathrm{XV}$ stulecia pochodzą malowane wizerunki panien roztropnych i nierozsądnych w kościele parafialnym pw. świętych Jana Chrzciciela i Jana Ewangelisty w Ornecie (prawdopodobnie powstałe w latach 1420-1430) ${ }^{54}$.

$\mathrm{W}$ epoce średniowiecza motyw nowotestamentowej przypowieści, licznie reprezentowany w rzeźbie i malarstwie ściennym, sporadycznie podejmowano również w sztuce witrażowej, m.in. w XIV w. panny wyobrażono w oknach katedr $\mathrm{w}$ Troyes i Miluzie ${ }^{55}$, ponadto zachowały się dwie postaci panien, mądrej i głupiej, na witrażu (ok. 1380-1390) zdobiącym prezbiterium kościoła Mariackiego w Krakowie ${ }^{56}$. Niekiedy parabolę przedstawiano w detalach konstrukcji ołtarzowych, np. w antependium z Getyngi (1360-1370, Berlin, Kunstgewerbemuseum), gdzie panny stoją po bokach Chrystusa Sędziego ${ }^{57}$. W zaginionej predelli poliptyku z kościoła św. Jana Chrzciciela

50 Odnośnie do wystroju malarskiego we wnętrzu kwidzyńskiej katedry vide L. Krantz, J. Domasłowski, Katedra i zamek w Kwidzynie, Warszawa-Poznań-Toruń 1952, s. 52 59; L. Krantz-Domasłowska, Katedra w Kwidzynie, Toruń 1999, s. 85-90.

51 T. Chrzanowski, M. Kornecki, Sztuka Śląska Opolskiego..., s. 109.

52 A. Karłowska-Kamzowa, Malarstwo śląskie..., s. 48.

53 Malarstwo gotyckie..., s. 119.

54 Ibidem, s. 83.

55 L. Réau, Iconographie..., s. 358.

56 Malarstwo gotyckie..., s. 126; L. Kalinowski i in., Średniowieczne witraże kościoła Mariackiego w Krakowie. Historia i konserwacja, "Studia i Materiały Wydziału Konserwacji i Restauracji Dzieł Sztuki Akademii Sztuk Pięknych w Krakowie" 1997, t. 7, s. 52, 56-57.

57 Z. Kliś, Paruzja..., s. 180. 
w Stargardzie Szczecińskim (ok. 1460) panny otaczały Chrystusa - Oblubieńca $^{58}$. Na przestrzeni lat osiemdziesiątych XV stulecia ewangeliczny temat podjął Martin Schongauer, autor cyklu dziesięciu grafik ukazujących każdą pannę z osobna, który jednak bardziej niż na oddaniu eschatologicznego nastroju skupił się na wyeksponowaniu kobiecej anatomii. Wraz z końcem $\mathrm{XV}$ w. topos panien mądrych i głupich został w sztuce niemalże całkowicie zapomniany, występując w okresie nowożytnym już tylko na pojedynczych obrazach i rycinach.

\section{Bibliografia}

\section{Źródła}

Pismo Święte. Stary i Nowy Testament, red. ks. M. Peter, ks. M. Wolniewicz, Poznań 2010.

\section{Opracowania}

BIAŁŁOW ICZ-KRYGIEROWA Z., Malowidła ścienne $z$ XIV wieku w dawnym opactwie cysterskim w Lądzie nad Wartą, Poznań 1957.

BIAŁŁOWICZ-KRYGIEROWA Z., Malowidła ścienne $z$ XIV wieku $w$ dawnym opactwie cysterskim w Ladzie nad Warta, rec. A. Karłowska, „Studia i Materiały do Dziejów Wielkopolski i Pomorza” 1962, t. 7, z. 1, s. 377-379.

BZÓWKA U., Treści ikonograficzne portalu grobowej kaplicy św. Anny na Zamku Krzyżackim w Malborku, „Roczniki Humanistyczne” 1975, t. 23, z. 5, s. $27-48$.

CHRZANOWSKI T., KORNECKI M., Sztuka Śląska Opolskiego. Od średniowiecza do końca wieku XIX, Kraków 1974.

DOMASŁOWSKI J., KARŁOWSKA-KAMZOWA A., KORNECKI M., MAŁKIEWICZÓWNA H., Gotyckie malarstwo ścienne w Polsce, Poznań 1984.

Encyklopedia biblijna, red. P. J. Achtemeier, przeł. G. Berny, M. Bogusławska i in., Warszawa 1999.

FRANCE R. T., The Gospel According to Matthew: An Introduction and Commentary, Leicester 1985.

FRIEDMAN L. J., On the Structure of Joinville's Credo, "Modern Philology" 1953, Vol. 51, No. 1, s. 1-8.

FRIEDMAN L. J., Text and Iconography for Joinville's Credo, Cambridge 1958. GREISENEGGER W., Ecclesia und Synagoge, [w:] Lexikon der christlichen Ikonographie, t. 1, red. E. Kirschbaum, Rom-Freiburg-Basel 1968, szp. 569-578.

$58 \quad$ Malarstwo gotyckie..., s. 254. 
HALL E., UHR H., Aureola and Fructus: Distinctions of Beatitude in Scholastic Thought and the Meaning of Some Crowns in Early Flemish Painting, "The Art Bulletin" 1978, No. 2, s. 249-270.

HOLLADAY J. A., Wise and Foolish Virgins, [w:] Medieval Germany: An Encyclopedia, ed. J. M. Jeep, New York 2001, s. 395-396.

JAGLA J., Wieczna prośba i dziękczynienie. O symbolicznych relacjach między sacrum i profanum w przedstawieniach wotywnych $z$ obszaru Polski Centralnej, Warszawa 2009.

JAKUBOWSKA B., Malborska Summa theologica, [w:] T. GUĆ-JEDNASZEWSKA, B. JAKUBOWSKA, Z. KRUSZELNICKI, Studia zhistorii sztuki Gdańska i Pomorza, Wrocław-Warszawa-Kraków 1992, s. 157-247.

JAKUBOWSKA B., Złota Brama w Malborku. Apokaliptyczne bestiarium w rzeźbie średniowiecznej, Malbork 1989.

JANKOWSKI A., ROMANIUK K., STACHOWIAK L., Komentarz praktyczny do Nowego Testamentu, cz. 1, Poznań-Warszawa 1975.

JENSEN R. M., Baptismal Imagery in Early Christianity: Ritual, Visual and Theological Dimensions, Grand Rapids 2012.

KALINOWSKI L., MAŁKIEWICZÓWNA H., HEINE L., KARASZKIEWICZ P., Średniowieczne witraże kościoła Mariackiego w Krakowie. Historia $i$ konserwacja, „Studia i Materiały Wydziału Konserwacji i Restauracji Dzieł Sztuki Akademii Sztuk Pięknych w Krakowie" 1997, t. 7, s. 13-96.

KARŁOWSKA-KAMZOWA A., Malarstwo ślaskie 1250-1450, Wrocław-Warszawa-Kraków 1979.

KLIŚ Z., Paruzja. Przedstawienie Sądu Ostatecznego w sztuce średniowiecznej Europy Środkowej, Kraków 1999.

KRANTZ L., DOMASŁOWSKI J., Katedra i zamek w Kwidzynie, WarszawaPoznań-Toruń 1952.

KRANTZ-DOMASŁOWSKA L., Katedra w Kwidzynie, Toruń 1999.

LEWIS S., Tractatus adversus Judaeos in the Gulbenkian Apocalypse, "The Art Bulletin" 1986, No. 4, s. 543-566.

LURKER M., Przesłanie symboli w mitach, kulturach i religiach, tłum. R. Wojnakowski, Kraków 1994.

Malarstwo gotyckie w Polsce. Katalog zabytków, red. A. S. Labuda, K. Secomska, Warszawa 2004.

MICHAEL R., A History of Catholic Antisemitism: The Dark Side of the Church, New York 2008.

OROSZ A., Gotycka polichromia w kościele w Strzelcach Świdnickich, „Kwartalnik Opolski” 1956, nr 1(5), s. 172-190.

PIJOAN J., The Parable of the Virgins from Dura-Europos, "The Art Bulletin" 1937, No. 4, s. 592-595. 
RÉAU L., Iconographie de l' art chrétien. Iconographie de la Bible. Nouveau Testament, vol. 2, Paris 1957.

ROSENAU H., Ecclesia et Synagoga, [w:] Encyclopaedia Judaica, t. 6, eds. F. Skolnik, M. Berenbaum, Detroit-New York-San Francisco 2007, s. 88.

ROWE N., The Jew, the Cathedral, and the Medieval City: Synagoga and Ecclesia in the Thirteenth Century, Cambridge 2011.

RYKEN L., WILHOIT J. C., LONGMAN III T., Słownik symboliki biblijnej. Obrazy, symbole, motywy, metafory, figury stylistyczne igatunki literackie w Piśmie Świętym, tłum. Z. Kościuk, Warszawa 2003.

SACHS H., Jungfrauen, Kluge und Törichte, [w:] Lexikon der christlichen Ikonographie, t. 2, red. E. Kirschbaum, Rom-Freiburg-Basel 1970, szp. 458-463.

SCHLAUCH M., The Allegory of Church and Synagogue, "Speculum" 1939, Vol. 14, No. 4, s. 448-464.

SEIFERTH W. S., Synagoge und Kirche im Mittelalter, München 1964.

SIMSON O., VON, Katedra gotycka. Jej narodziny i znaczenie, tłum. A. Palińska, Warszawa 1989.

SKIBIŃSKI S., Kaplica na Zamku Wysokim w Malborku, Poznań 1982.

ZLATOHLÁVEK M., RÄTSCH C., MÜLLER-EBELLING C., Sąd Ostateczny. Freski, miniatury, obrazy, tłum.. A. Kleszcz, Kraków 2002. 